\title{
COMPENSATION FOR A PARTIAL TAKING OF PROPERTY: BALANCING FACTORS IN EMINENT DOMAIN*
}

THE physical expansion of urban areas can pose conflicts with property owners unwilling to follow the trend towards urbanization. While improving a road in a developing suburban area near Nashville, the county diverted a stream from land used as a riding academy. This diversion rendered use of the land for this purpose more difficult, but did not affect the market value of the property. Measured by the value placed on the property by the owner-a subjective standard-he has been damaged by the action of the county; according to the objective standard of the market place, there was no damage. In the eminent domain proceeding arising from the diversion of the stream, the court applied a market value measure to this partial taking of property being used at less than its highest economic use $;^{1}$ it concluded that no compensation need be paid. This result seems inconsistent with the social interest in minimizing the effect of government action on property rights.

A central value in our system of private property is the freedom of the individual property owner to use and dispose of his property as he sees fit." Courts, in scrutinizing governmental restrictions on the use of property, have traditionally afforded substantial protection to individual volition in the use of private property. Thus, exercises of the police power restricting the utilization of property must be found to be reasonable. ${ }^{3}$ Although eminent domain-the power of government to compel the sale of private property-represents a

*Evans v. Wheeler, 348 S.W.2d 500 (Tenn. 1961).

1. The highest use of land is the use for which the property is suitable that would command the highest price in the market place. In the instant case, the land involved had a highest use as a residential subdivision: The present use-a riding academy-is a lessthan-highest use.

2. Men have various interests in land. Important among these is the interest in its exclusive possession free from interferences by physical intrusions of other's or things controlled or set in motion by them. The interests in quiet enjoyment and exclusive use of land and structures on it are the oldest interests recognized and protected by the common law. Anglo-Americans and, indeed, citizens of most civilized nations like to feel that their land is their own and that they can do as they please with it. This, of course, is not, and for that matter never has been literally true, for the

. obvious reason that society must regulate and control the use made by one person of his property so that undue injury may not be caused to others. Nevertheless, the interest of a possessor in his land has, from the beginning, received very wide legal protection.

1 Harper \& JaAres, The LAw of ToRts $\$ 1.1$ at 4 (1956).

The most obvious restriction on unfettered private volition is that property cannot bo used illegally, and that an illegal use will not be protected. Musco v. Torello, 102 Conn. 346, 128 Atl. 645 (1925). Nor can property be used in such a way as to be a nutisance. May. flower Holding Co. v. Warrick, $143 \mathrm{Fla} .125,196$ So. 428 (1940).

3. Compare Village of Euclid v. Ambler Realty Co., 272 U.S. 365 (1926), with Nectow v. City of Cambridge, 277 U.S. 183 (1928). 
shortcut by which the community can attain potentially expensive goals at a reasonable cost, ${ }^{4}$ the prerequisites to the exercise of the power-that it be used for a public purpose and that just compensation be paid "-show that it also represents a balance between the needs of the community and the protection of private property.

Once property has been taken, the requirement of just compensation means that concepts of property rights and protection of these rights must find their equivalent in the determination of property value. ${ }^{0}$ Ideally, compensation should restore the owner of the taken property to the same position he would have occupied had his property not been taken. ${ }^{7}$ Since the value of the taking may

4. Eminent domain is a "shortcut" in that it allows the community to determine what property it needs and then to take that property despite the wishes of the owner, subject to the requirement that the owner be paid a fair price for what is taken. The power of eminent domain is an inherent power of sovereignty. Johnson v. Joliet \& C.R.R, 23 IIl. 202 (1859). The power can be used by federal, state, and local governments, as well as by a large variety of specialized local governmental bodies, such as sewage and park districts, and by some public utilities. See 1 Nichols, EarrNent Dosrain $\S \S 3.1-3.232$ (3d ed. 1950). [Hereinafter cited as NicHoLs.]

5. "[N]or shall private property be taken for public use, without just compensation." U.S. Const. amend. V. The requirement that the taking be for a public purpose is implicit in the first clause of the guarantee. For a list of uses that fall within public purpose, see JAHR, EMTNENT DoManIN 22-25 (1953) [hereinafter cited as JAHR]. State constitutional and statutory requirements relating to eminent domain are collected in Appendix, $48 \mathrm{~V}_{\mathrm{A}}$. L. REv. 548 (1962).

6. This function of compensation in eminent domain is recognized by so carly a commentator as Blackstone.

So great moreover is the regard of the law for private property, that it will not authorize the least violation of it; no, not even for the general good of the whole community. If a new road, for instance, were to be made through the grounds of a private person, it might perhaps be extensively beneficial to the public; but the law permits no man, or set of men, to do this without consent of the owner of the land. In vain it may be urged, that the good of the individual ought to yield to that of the community; for it would be dangerous to allow any private man, or even any public tribunal, to be the judge of this common good, and to decide whether it be expedient or no. Besides, the public good is in nothing more essentially interested, than in the protection of every individual's private rights, as modelled by the municipal law. In this and similar cases the legislature alone can, and indeed frequently does, interpose, and compel the individual to acquiesce. But how does it interpose and compel? Not by absolutely stripping the subject of his property in an arbitrary manner; but by giving him a full indemnification and equivalent for the injury thereby sustained .... All the legislature does is to oblige the owner to alienate his possessions for a reasonable price...

1 Blackstone, Conarentaries 139 (1758).

7. Such compensation means the full and perfect equivalent in money of the property taken. The owner is to be put in as good a position pecuniarily as he would have occupied if his property had not been taken.

United States v. Miller, 317 U.S. 369, 373 (1942). The difficulty of accurately evaluating property in terms of money is illustrated by the established practice of granting specific 
differ as between the owner and the taker, the courts have sought a measure of compensation that is fair to both, and have often, but not always, rejected the subjective standards of "value to the taker" and "value to the owner." The objective standard generally adopted, market value, in which a natural bargaining situation is approximated by positing a voluntary seller and a voluntary buyer, ${ }^{9}$ often affords adequate protection to the property owner, regardless of his use of the property prior to the taking. For example, where the government takes an entire tract of land-a total taking - the owner would be paid an amount based upon the highest or most profitable use to which the property could be put, regardless of actual use. Thus, the property owner is in no way "penalized" for using his land at less than its most economic use. ${ }^{10}$ Since the market value standard is only an incantation, and not a rigid definition, ${ }^{11}$

performance of almost all contracts to convey land. See, c.g., Gartrell v. Stafford, 12 Neb. 545, 11 N.W. 732 (1882).

8. Value to the taker has been universally rejected as a standard. 1 ORGEL, VALUATION UNDER EMINent Domain $\$ 81$ (2d ed. 1953) [hereinafter cited as Orget]; 4 Nicriols $\$ 12.21$. If value to the taker were to be used as the standard of compensation, the advantage that the eminent domain power gives to the government in fulfilling its obligations, the advantage of avoiding the open market, would be all but lost. Value to the owner has usually been rejected, too, for it is open to the subjective influences of human irrationalities on the one hand, and often closely approximated by market value on the other. Sec 1 Onces $\S \S 66-80 ; 4$ Nichols $\S 12.22 ; 1$ Bonbright, Valuation of Property 66-97 (1937).

9. The creation of a bargaining situation between a willing seller, not forced to sell, and a willing buyer, not compelled to purchase, is intended to prevent the setting of value in terms of the seller having to make a forced sale, or of the buyer being "held-up" bectuse of his need for the property. It has also been used to apply the market value standard to property for which there is no market, by assuming that such a market does exist. 1 BoNBRIGHT, op. cit. supra note 8, at 59-61; see 4 NICHOLS \$ 12.2[1]; 1 ORGEL \$\$ 22-23.

10. The requirement that market value be computed in view of all reasonably probable uses recognizes that the present use of property does not alone determine its value.

The sum required to be paid the owner does not depend upon the uses to which he has devoted his land but is to be arrived at upon just consideration of all the uses for which it is suitable. The highest and most profitable use for which the property is adaptable and needed or likely to be needed in the reasonably near future is to be considered, not necessarily as the measure of value, but to the full extent that the prospect of demand for such use affects the market value while the property is privately held.

Olson v. United States, 292 U.S. 246, 255 (1934). For example, if a man owned land that he used as a farm, and that land was known to contain a gold mine, its price on the open market would be determined by its value as a gold mine, its highest use, rather than by its value as a farm. See 1 Orger $\S 20$.

11. See 1 Orgel $\$ 15$ at 79.

It must also be remembered that market value is an approximation, rather than an exact measure, of the cash exchange value of property. Cases in which there are large differences in the estimates of the market value of property are common. See, c.g., Oklahoma City v. Wilson, 310 P.2d 369, 372 (Okla. 1957) ( $\$ 4,200$ as against $\$ 42,400$ ) ; State Roads Comm'n v. Nevosel, 203 Md. 619, 625-26, 102 A.2d 563, 566 (1954) ( $\$ 2,000$ as against $\$ 54,348$ ). A more striking example of the inexact nature of market value can be derived from ten cases 
courts are able to find in it a flexibility which allows them to arrive at a fair result in most situations. So, in a partial taking situation, where the sum of the individual values of the component parts does not equal the value of the whole, the property owner is compensated for the value he has lost-i.c., the value of the part taken, plus damages to the remainder, or the value of the whole tract before the taking, minus the value of the remainder after the taking-rather than for the market value of what was taken. ${ }^{12}$ Furthermore, although compensating the property owner for interference with a particular use of property is anathema in the law of eminent domain, ${ }^{13}$ the market value used is nevertheless often computed "in view of the adaptability of the property for a special use." This use is usually the use to which the property is in fact being put. For ex-

passed upon by the Governor's Council of Massachusetts in December, 1957, in all of which appraisals were made by outside appraisers called in by the state.

$\begin{array}{ccc}\text { Lower Appraisal } & \text { Higher Appraisal } & \text { \% Difference } \\ \$ 1,272 & \$ 4,141 & 221 \\ 10,500 & 13,773 & 31 \\ 23,000 & 33,500 & 46 \\ 1,874 & 3,653 & 95 \\ 17,500 & 24,300 & 39 \\ 53,600 & 54,500 & 2 \\ 7,800 & 8,552 & 10 \\ 1,312 & 7,623 & 481 \\ 23,000 & 23,500 & 2 \\ 26,310 & 67,300 & 156\end{array}$

(Figures taken from weekly calendars of Governor's Council meetings, Dec. 1, 1956-Jan. 2, 1957.)

12. For example, a farm might have a market value of $\$ 10,000$, while each of its halves would be worth only $\$ 3,000$ if sold separately. The market value of a half would thus be $\$ 3,000$, while its value to the owner of the farm, and the extent of his injury if it were taken, would be $\$ 7,000$. See 1 OrgEL \& 52; 4 Nrchols $\S 14.1[2]$.

Three methods of calculating severance damages in such cases have been used. The usual method is to compute the market value of the part taken plus the damages to the remainder. 1 ORGEL $\S 51$; JAHR 136 . The other method commonly used involves measuring the difference between the fair market value of the property before and after the taking. 1 ORGEL § 50; JAHR 136-38. A third method, first used in Louisiana Soc'y v. Board of Levee Comm'rs, 143 La. 90, 78 So. 249 (1918), has little practical significance. See 1 Orger. § 49; JAHR 138.

13. And this just compensation, it will be noticed, is for the property, and not to the owner. Every other clause in this Fifth Amendment is personal. "No person shall be held to answer for a capital or otherwise infamous crime," etc. Instead of continuing that form of statement, and saying that no person shall be deprived of his property without just compensation; the personal element is left out, and the "just compensation" is to be a full equivalent for the property taken.

Monongahela Navigation Co. v. United States, 148 U.S. 312, 326 (1893). This interpretation of the protection afforded by the fifth amendment, an interpretation still adhered to, climinates as an element of compensation injury to such "personal" factors as the use being made of property. See generally OrGer §§ 2-3. But see Cormack, Legal Conecpts in Cases of Eminent Domain, 41 YALE L.J. 221, 257-58 (1931) ("The decision as to whether compensation should be made generally has been reached, however, upon purely legalistic grounds with a physical conception of the eminent domain process in mind."). 
ample, in Housing Authority of Bridgeport v. Lustig, 14 the court, although stating that the owner may not be compensated for injury to the property's use as a slaughterhouse, held that the fact the property was used to conduct a slaughterhouse justified an award of $\$ 18,309$. The value of the property, in the absence of the established business, was found to be $\$ 8,309.16$ Finally, where there is no available market for the property taken, or where the market value standard would lead to a grossly inequitable result, courts abandon the market value standard altogether, claiming to compensate the owner for the "intrinsic value of the property,"16 its value to the owner, ${ }^{17}$ or the cost of preventing

14. 139 Conn. 73, 90 A.2d 169 (1952).

15. The verbal efforts of the courts to maintain the classic dichotomy of eminent domain law between use and property, first set forth by Mr. Justice Brewer in Monongahela Navigation Co. $v$. United States, note 13 supra, reach a confusing extreme in cases similar to Lustig. Thus, in Mitchell v. United States, 267 U.S. 341 (1925), the Court stated:

The special value of the land due to its adaptability for use in a particular business is an element which the owner of land is entitled ... to have considered in determining the amount paid as just compensation....

Id. at 344-45. But the Court also ruled that the destruction of the business that resulted from the taking was an unintended incident of the taking, and was not an element of compensation.

Similar, and no more meaningful, distinctions can be found in many cases in which the use of the property is not particularly extraordinary. An example of such a case is Causby v. United States, $60 \mathrm{~F}$. Supp. 751 (Ct. Cl. 1945), rev'd on other grounds, 328 U.S. 256 (1946). Causby's property was used as a chicken farm, over which Air Force planes flew frequently at low altitude. The court held that there was a taking of property. On the measure of damages, the court said:

Plaintiffs are not entitled to recover for the damage to their business, but they are entitled to recover the special value of the land due to its adaptability for use for this business.

$60 \mathrm{~F}$. Supp. at 758. It appears difficult to conceive of Causby's property having any unique value because of its ability to be used as a chicken farm. The U.S. Supreme Court reversed on other grounds, without discussing the issue of damages. United States v. Causby, 328 U.S. 256 (1946). See also Montana-Dakota Util. Co. v. Culver, 80 N.W.2d 541 (N.D. 1957), in which evidence of the contour plowing method used was allowed as evidentiary of the value of the property taken by condemning a power line easement through a farm.

16. Lower Colorado River Authority v. Hughes, 122 S.W.2d 222, 223 (Tex. Civ. App. 1938) :

Appellees alleged and tried their case on the theory that the property had no markct value, but that it had an actual, reasonable or intrinsic value; and the rule is settled that when property taken or destroyed has no market value, its actual, reasonable, or intrinsic value may be shown.

The idea that property has an intrinsic value seems to conflict with the concept of market value providing the best measure of the value of property. Intrinsic value is frequently equated with value to the owner.

17. See, e.g., Board of Park Comm'rs of City of Wichita v. Fitch, 184 Kans. 508, 337 P.2d 1034 (1959) (tract containing two lakes and a sandy beach); State v. Dunclick, Inc., 77 Idaho 45, 286 P.2d 1112 (1955) (storage land of manufacturing plant; lower court opinion reversed on other grounds) ; Sanitary Dist. of Chicago v. Pittsburg, Ft. W., \& C. Ry., 216 I11. 575, 75 N.E. 248 (1905) (part of freight terminal); also see 4 Nicirous $\$ 12.32$; 1 ORGEL $\S \S 39-42$. 
damage to the owner. ${ }^{18}$ Thus, where the property condemned was an expensive house in a run-down neighborhood, it was held that, in fixing compensation, "the intrinsic value, or its value to the owner must be taken into consideration; otherwise he might be deprived of his property without just and reasonable compensation."19 In these situations cost of construction, loss of profits, and cost of repair are taken into account in determining the amount of the award.

Evans $v$. Wheeler ${ }^{20}$ presents another situation where compensation in terms of market value presents difficulties. Jay Evans owned seventy acres of land on the outskirts of Nashville. On the western side of a bisecting road he

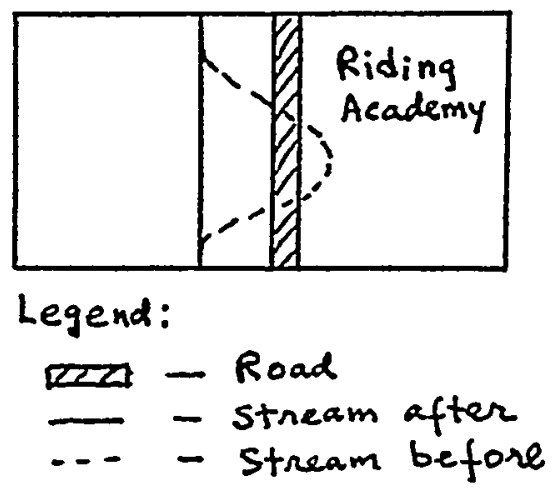

operated a farm; on the east, a riding academy. A stream, Cooper Creek, ran through the farm, curving across the road from west to east and then back

18. The payment of the cost of replacing or repairing taken facilitics, where such cost is less than the damage to the value of the land caused by the taking, has been adopted as a method of making just compensation. Actually, this cost is only the decrease in the market value of the property, in view of the owner's duty to curtail the damage from the taking. Little v. Burleigh County, 82 N.W.2d 603, 613 (N.D. 1957) (lower court opinion reversed on other grounds) ; Town of Oneida v. Hail, 105 S.W.2d 121 (Ct. App. Tenn. 1937) (cost of retaining wall, to prevent further erosion caused by the town's action); United States v. Martin, 267 F.2d 764, 771 (10th Cir. 1959) (Government project stopped overfow of river, which was a source of natural irrigation. "An adequate irrigation system, or the cost thereof, judicially determined, may indeed equal just compensation for the impairment of the overflow rights.").

19. Housing Auth. of Shreveport v. Green, 200 La. 463, 474, 8 So.2d 295, 293 (1942). Also see Housing Auth. v. Savannah Iron \& Wire Works, Inc., 91 Ga. App. 881, 87 S.E.2d 671 (1955), in which the following charge to the jury was approved:

I further charge you, gentlemen, that the Constitutional provision as to just and adequate compensation does not necessarily restrict the lessec's recovery to market value. The lessee is entitled to just and adequate compensation for his property; that is, the value of the property to him, not its value to the Housing Authority. The measure of damages for property taken by the right of eminent domain, being compensatory in its nature, is the loss sustained by the owner, taling into consideration all relevant factors.

Id. at $884-85,87$ S.E.2d at 675 (italics omitted).

20. 348 S.W.2d 500 (Tenn. 1961). 
across to the west side of the road. The land around Evans' farm was being developed as residential subdivisions, and the east half of Evans' land was suitable for subdivision development. The west half, however, was subject to flooding, and was suitable only for use as farm land. In the course of improving the road, the county relocated the creek entirely on its western side, eliminating the need for two bridges which would have cost $\$ 25,000$. Evans sued for $\$ 20,000$ in damages, the alleged decrease in the value of his property as a riding academy due to the lack of water. ${ }^{21}$ The Chancellor determined that the diversion of the stream was a taking, and appointed a Master to assess the compensation due Evans. ${ }^{22}$ The Master found that the "highest use value," or market value, of the land was for subdivision purposes. The relocation of the stream did not reduce this value. Therefore, the Master concluded, "the diversion of Cooper Creek by the county has not resulted in any damage to the complainant."23 The Master also found that water could be pumped from the relocated creek to the east side of the road at a cost of $\$ 800-\$ 1,000.24$

The opinion of the Master was affirmed by the lower courts and by the Tennessee Supreme Court. ${ }^{25}$ This court, taking up the challenges to the Master's report separately, ${ }^{26}$ agreed that the diversion of the stream by the county

21. This case is the culmination of a series of litigations in which Evans had been involved. The first suit concerned an alleged oral contract with his brother involving an adjacent piece of land, and an alleged inducing of his brother by a third party to breach that contract. Evans was denied recovery, due to the Tennessee rule that a third party can invoke the statute of frauds as a defense. Evans v. Mayberry, 198 Tenn. 187, 278 S.W.2d 691, rehearing denied, 279 S.W.2d 705 (1955). In the instant case, Evans was apparently attempting to impede the development of subdivisions on the land surrounding his farm, including the land involved in the former suit. He built fences that blocked the road at both ends of his land. When these were torn down, he sued to enjoin the county from tearing them down again. He also revived his claim of inducing a breach of contract, attempted to enjoin the county, as a taxpayer, from constructing a road to subdivisions that were just beginning construction, and claimed damages resulting from the relocation of his strcam. Complaint of Appellant (on file at Yale Law Library). All of these claims for relief were denied. Chancellor's Decree and Opinion of the Court of Appeals (on file at Yale Law Library).

22. The full title of a master in Tennessee practice is Clerk and Master.

23. Clerk and Master's Report, p. 3 (on file at Yale Law Library).

24. Ibid.

25. The opinions of the lower courts have not been published. The Supreme Court granted limited certiorari, and considered only the issue of compensation for the taking of the stream. Memo to Counsel Limiting Certiorari, March 10, 1961 (on file at Yale Law Library). The opinion of the Supreme Court was written by Judge Tomlinson, who also wrote the opinion in Evans v. Mayberry, 198 Tenn. 187, 278 S.W.2d 691, rehearing denicd, 279 S.W.2d 705 (1955).

26. There is no indication in the opinion that the court either viewed the situation presented as a whole or analyzed the probable effect of its decision. Apparently, the court assumed it was applying standard doctrines to the case, bringing the situation created by the action of the county to its logical conclusion.

This is, perhaps, excusable in view of the failure by counsel to fully present the problem in their briefs-appellant proceeds primarily on a trespass theory; appellee argues that the findings of the Master, Chancellor, and Court of Appeals should be binding. (Briefs on file at Yale Law Library.) 
was a taking of Evans' property. On the subject of compensation, the Court stated that market value is the standard by which damages are assessed, unless the use is one peculiar to the owner, and rejected Evans' contention that his riding academy is such a use. ${ }^{27}$ Then, using the objective standard of market value, the Court found that Evans had suffered no damage from the taking.23 Finally, the Court rejected the solution of paying Evans $\$ \$ 00-\$ 1,000$, the cost of replacing the diverted water, on the ground that to allow this cost as the measure of damages in this case would be to establish a dangerous precedent."0

The necessary effect of denying any compensation to Evans for the taking of his stream is to make it more difficult for him to continue his use of the land as a riding academy. ${ }^{30}$ Evans must either bear the cost of installing a pump in order to continue his prior use, find another use, or sell his land for residen-

27. The court rejected Evans' argument by stating that "any other owner, as well as Evans, could operate a riding academy on the 43 acres. So its use is not one peculiar to Evans." 348 S.W.2d at 505. Though Evans' use might not be one that is peculiar to the owner, the Court's reliance on this rationale robs this exception to the generally used standard of market value of all meaning, for even a church or a railroad station could be operated on the same property by a different person. A case falling within the peculiar use exception is Southern Ry. v. City of Memphis, 126 Tenn. 267, 148 S.W. 662 (1912) (part of railroad yard taken).

28. The court stated, correctly, that the usual measure of damages in cases of taking of riparian rights is the difference in value of the riparian lands before and after the talking, and found that by this measure Evans has not been damaged. 348 S.W.2d at 506. This measure of compensation has been adopted because of the extreme difficulty of evaluating a stream of water, per se. It is used as the standard most likely to compensate the owner for the damage done to him by the taking. An example of a case where it serves this purpose is Albaugh v. Mount Shasta Power Corp., 9 Cal. 2d 751, 73 P.2d 217 (1937). The Tennessee court did not, however, examine the reason for the rule, but seemed merely to apply it as an ironclad standard. Such application is incorrect, for the rule is not an absolute test. Compensation has been based on the intrinsic value of the water, i.e., its value as water. Whitmore v. Utah Fuel Co., 42 Utah 470, 482, 131 Pac. 907, 912 (1913) (Compensation set by the value of the water to the owner, in view of all the purposes for which he is using it. And note Straup, J., concurring: "So in estimating the value of the water I think the plaintiff should be permitted to show, not only the uses which he had made of the water, but also the uses which naturally and ordinarily could have been made of it."). Water has also been evaluated for its utility as a flowing stream. King v. Board of Council of City of Danville, 107 S.W. 1189 (Ct. App. Ky. 1908) (Plaintiff entitled to damages for diversion of stream, which prevented him from operating his mill, though there was no market for the products of the mill.). Finally, damages in a riparian taking case have been based on the cost of replacing the water. See United States v. Alartin, 267 F.2d 764 (10th Cir. 1959) (discussed in note 18 supra).

29. 348 S.W.2d at 506-07. As the cost of replacing the water on Evans' land is considerably less than the alleged loss in the value of the land as a riding academy after the taking, this cost of replacement would be the correct measure of damages in this case. See note 18 supra. The court based its rejection of this measure of damages on the rationale that to allow the cost of replacing water to be the general rule would lead to ridiculous results in many cases, as where the water level of a river is lowered.

30. Whereas Evans formerly could turn his horses loose and allow them to water themselves, it is now necessary either to bridle each horse and lead him across the road to be watered or to build a pump for conducting water to the east side of the road. 
tial development, its highest economic use. If a "zoning out" of Evans' equine establishment was one of the objectives of the county in relocating the stream, to allow the community to accomplish this objective through a partial taking seems highly questionable. ${ }^{31}$ True, the community could have passed a zoning ordinance requiring that the land be used for residential purposes; but constitutional standards of due process require that zoning ordinances making an existing use nonconforming must provide a reasonable time, usually a period of years, between passage of the ordinance and the required termination date $;^{a 2}$ failure to allow such a period is a denial of due process-a taking of property without just compensation. ${ }^{33}$ The rationale is that the allowance of a reasonable time and the creation of a virtual monopoly during this period will permit amortization of the loss resulting from the termination..$^{34}$ The change from stable to residence could also have been achieved through a taking of the entire tract of land, followed by a sale of the land for residential development. In the absence of other circumstances, however, a taking for the purpose of inducing highest economic use might not have fulfilled the public purpose requirement of eminent domain. ${ }^{35}$ Thus allowing the partial taking of the property in this

31. The "zoning out" would occur if, as a result of increased costs, Evans sold his land for residential development.

32. See, c.g., Baltimore, Md., Ordinance 711, $\Uparrow 13(\mathrm{~d})$ (May 21, 1953) (5 years) ; City of Buffalo, N.Y., Ordinances, ch. LXX $\$ 18$ (1953) (3 years).

33. See Adams v. Kalamazoo Ice \& Fuel Co., 245 Mich. 261, 264, 222 N.W. 86, 87 (1928) ("The legitimate purpose of a zoning ordinance . . . is to preserve and not to disrupt existing conditions.") ; Jones v. City of Los Angeles, 211 Cal. 304, 295 Pac. 14 (1931) (Ordinance requiring termination of the use of property as a hospital for the mentally ill held unconstitutional.) ; cf. City of Plainfield v. Borough of Middlesex, 69 N.J. Super. 136, 173 A.2d 785 (1961); Town of Somers v. Comarco, 308 N.Y. 537, 127 N.E.2d 327 (1955) (Ordinance preventing sand and gravel pit operators to get a permit before continuing their non-conforming use held "to deprive the defendants of a 'vested' right. . . ."). It is interesting to note that in these cases the only property being taken is a use of the laud.

34. See Harbison v. City of Buffalo, 4 N.Y.2d 553, 152 N.E.2d 42 (1958) (note dissenting opinion of Van Voorhis, J., discussing rationale of "amortization"). The rationtale of "amortization" had early expression in Note, 9 U. CHI. L. REv. 477 (1942).

35. Schneider v. District of Columbia, 117 F. Supp. 705 (D.D.C. 1953), interpreting the District of Columbia Redevelopment Act of 1945, held that land could be taken and resold to a private person only where the taking is necessary to eliminate or prevent a slum. This holding was modified in Berman v. Parker, 348 U.S. 26 (1954). The Court held that making an area aesthetically consistent was a valid purpose of eminent domain condemntation, and that a private party could be designated by Congress as the agency of redevelopment. The scope of this holding is limited, however, in that the general area involved hand been determined to be "blighted."

In the instant case, it is a close question as to whether Evans' land could be condemncd and resold for residential development. Even if it did fulfill the requirement of public purpose, the county would have to make a major, though temporary, outlay of capital to accomplish such a goal, and it has not indicated a willingness to do so.

An interesting contrast to this is provided by the planning acts of some metropolitan areas in England, which make provision for the development agency to buy up land near an improvement and then to sell it for development, thus realizing for itself the increase in value caused by the improvement. Lawrence \& Chavassee, Compulsony Purcinase and CoMprensation 185-86 (1958). 
case to have the effect of discouraging its present use is to permit the county to achieve an objective, indeed if it has such an objective, ${ }^{30}$ without an amortization period, as would be required in the case of an exercise of the zoning power, or without affording the landowner an opportunity to challenge the premise that the overriding public interest warrants this encroachment, as would be necessary in the case of a total taking.

The court in Evans, however, may have been influenced by doctrines embedded in eminent domain law, which seemingly preclude recovery in the Ezans situation. The fifth amendment's guarantee, "nor shall private property be taken for public use, without just compensation," has been construed to afford protection only to a right in rem, not in personam, and therefore the damage resulting from the taking is to be measured in terms of injury to property, rather than to the property owner. The actual use being made of property is considered to be a personal right and thus not subject to the requirement of compensation. ${ }^{3 \pi}$ But many cases hold, especially where another measure of damages would be inadequate, that the value the owner is entitled to recover is to be determined in view of the particular use to which the land is in fact put. ${ }^{38}$ The due process requirement of reasonable time before elimination of a nonconforming use in zoning law further indicates that enjoyment of actual use is a property right worthy of judicial protection. ${ }^{39}$ Moreover, present use, not potential or pos-

36. The clear purpose of the county in this case was to improve the road at the lowest cost. Viewed in this light, any effect of the taking on land use would seem to be incidental. The very building of a road that was not required by the previous land use in the area may indicate approval of the new land use, but there are also indications that the county may have approved of Evans' riding academy. The zoning of and the tax assessment on Evans' land were both conducive to his present use. While it is true that such policies are generally formulated for a whole community, rather than in relation to one land-owner, they can be used as instruments of land planning to indicate disapproval of a relatively specific use of land. See generally Comment, Mfunicipal Real Estate Taxation as an Instrument For Community Planning, 57 Y ALE L.J. 219 (1947).

The seemingly incidental effects may in fact be related to community concern with land use. Presumably, a minimum community goal is to have property put to a use for which it is at least moderately suited. Beyond this, if the community is not indifferent, it may have various positive objectives. It may want to have all land put to its highest use, as determined by the market place. The widespread use of zoning, which frequently causes land to be used at less than its highest use, indicates that the community often wishes to have other values, as well as those of the market place, influence land use. The authorities may also have an interest in retaining open space-either for its present qualities or to anticipate future needs.

37. See note 13 supra and accompanying text.

38. See notes 14-15 stpra and accompanying text.

39. See notes 31-34 sipra and accompanying text. Cf. Father Basil's Lodge v. City of Chicago, 393 Ill. 246, 65 N.E.2d 805 (1946).

"Property" has been defined to include every interest anyone may have in any and every thing that is the subject of ownership by man, together with the right to frecly possess, use, enjoy or dispose of the same; and this right of user, which is part of the property right guaranteed by the constitutions cannot be wholly taken away or limited by the State except in so far as it may become necessary for the individual rights to yield to the higher and greater law of the best interests of the people.

393 III. at 256,65 N.E.2d at 812. 
sible uses, is often considered in determining whether a particular interference is to be classified as a taking. ${ }^{40}$ These cases may be viewed as a tacit admission that the value of property and the value owing to a particular use cannot be separated, and thus that damage to property and damage to use are in this sense identical. This is not to say that the distinction between a loss due to an interference with use and injury resulting from a taking of property is no longer operative in the law of eminent domain, but that injury to use is in some situltions compensated, however obliquely.

Since the bar to compensation presented by traditional doctrines of eminent domain law has often proved to be illusory, and since a partial taking of property presents considerations not involved in a total taking situation, it would seem that courts should award damages to actual use for a partial taking of property utilized at less than its maximum economic use. ${ }^{41}$ Ideally, the purpose

40. See United States v. Causby, 328 U.S. 256 (1946) in which the taking of an air space easement over Causby's land is discussed primarily in terms of his use of the land as a chicken farm; cf. Erie County v. Fridenberg, 221 N.Y. 389, 117 N.E. 611 (1917) (well on plaintiff's land, dried up by blasting on other taken property, was also "taken").

Other essentially tortious acts of government have also been classified as takings. Sce Steinle v. City of Cincinnati, 142 Ohio St. 550, 53 N.E.2d 800 (1944) (escape of sewage was a taking of property, recovery denied on other grounds); City of Mansfield v. Balliett, 65 Ohio St. 451, 63 N.E. 86 (1902) (pollution of stream was a taking).This type of deviation from the strict doctrines of property and taking might be explained as merely an abandonment in substance of the doctrine of sovereign immunity, a doctrine that has been viewed with increasing disfavor. See Muskopf v. Corning Hospital Dist., $55 \mathrm{Cal}$. 2d 211, 11 Cal. Rpts. 89, 359 P.2d 457 (1961); Molitor v. Kaneland Community Unit Dist. No. 302, 18 Ill. 2d 11, 163 N.E.2d 89 (1959); Leflar \& Kantrowitz, Tort Liability of the States, 29 N.Y.U.L. REv. 1363 (1954). Such a view may also indicate an increased willingness to saddle the state, rather than any one individual, with various costs of state activities.

41. A situation similar to Evans would exist where a partial taking results in severance damages to the present use of the property, but not to the highest use.

Town of Slaughter v. Appleby, 235 La. 324, 103 So. 2d 461 (1958), illustrates such at situation. A strip of land through Slaughter's farm was taken for a road, impeding access from one part of the farm to another. The farm had a highest use as a residential subdivision, and the taking caused no severance damages to this use. The court allowcd an award based or the market value of what was taken, but refused to allow any award for severance damages.

True, defendants' witnesses were of the belief that severance damages might rcsult, they stating that the dividing of the tract might adversely affect defendants' livestock and farming operations. ... But obviously if a fixing of the value of the land taken is to be predicated on its potential residential use (as defendants contend for here) the determination of severance damages must be based on the same usage. Id. at 330-31, 103 So. $2 d$ at 464.

The resulting situation is one in which, if Slaughter wishes to continue his present use of the land, he will have to bear the burden of severance damages himself.

Another similar situation could arise as follows: A owns 100 acres of land which he operates as a farm. His land is located ten miles from Downtown, and is connected with Downtown by a rough paved road. His land is farm or marginal subdivision land, and has a market value of $\$ 500$ an acre. The state builds a superhighway from Downtown through A's farm, taking twenty acres of his land. As a result of the new road, and the consequent improved access to Downtown, his land is now prime subdivision land and has a marlict 
of compensation for any taking is to minimize the effect of the taking on the property owner. ${ }^{42}$ Where land used for any particular purpose is taken in its entirety, market value is usually adequate to minimize the effect of the taking, since, theoretically at least, the award enables the owner to purchase other land and thus to resume his prior use elsewhere. Moreover, an award based upon market value does not penalize him for using his property at less than its maximum economic use. However, where only a part of the property is taken and the damage to use is greater than the decrease in market value, ${ }^{43}$ application of the market value standard renders continuance of its present use more burdensome. Thus, it not only penalizes the owner for not using his land at its highest use but also fails to minimize the effect of the taking. Where only a part of the property is taken a remedy directed at actual maintenance of the owner's chosen use, not merely a monetary equivalent, is possible and frequently feasible. By awarding compensation based upon the amount necessary to enable the owner to continue his prior use, the effect of the taking may be abated. Although compensating the owner in this manner may result in a greater cost to the state than that required by the market value standard, preservation and encouragement of individual volition in the use of property-a right well protected in other areas of the law ${ }^{4}$-would seem to justify this additional cost. Increasing limits placed upon private volition do not gainsay the importance of this value, but merely reflect the increasing needs of the community. Although other community goals compete with the right of an individual freely to use his property, the goal of having land put to its highest economic use would not seem to be one of these. ${ }^{45}$ Indeed many of the recognized uses of zoning

value of $\$ 600$ an acre. In a state where the increase in the value of the remainder may be set off against the award, A would receive $\$ 2,000$. However, based upon its value as farm land, which is established by the producing capacity of the land, A would feel that he has lost $\$ 10,000$ worth of land. The only way that $A$ can become whole is to sell his land for subdivision purposes. That such a case could occur can be seen from the following statement:

The final inquiry as to the compensation to be awarded, if any, is the difference between the value of the entire tract immediately before the taking and the value of the part of the tract remaining after the taking, giving effect to any enhancement in value of the part remaining resulting from construction of the road. If the part remaining is worth as much as or more after completion of the project than the entire tract was worth immediately before the taking, the landowner has sustained no damage and is not entitled to any compensation.

Miorgan County v. Hill, 257 Ala. 658, 660, 60 So. 2d 838, 840 (1952); accord, Robinson v. State Highway Comm'n, 249 N.C. 120, 105 S.E.2d 287 (1958).

42. See notes 6-7 supra and accompanying text.

43. In some situations the decrease in the market value of the remainders will be greater than the damage to the less-than-highest use of the property. See, c.g., Herndon v. Pulaski County, 196 Ark. 284, 117 S.W.2d 1051 (1938). In such cases, the decrease in market value will, naturally, constitute the award.

44. See note 2 supra and accompanying text.

45. The market value standard itself generally operates to protect a less-than-highest use. See note 10 sipra and accompanying text. 
and eminent domain are designed to prevent land from being tsed in accordance with the dictates of the market place. ${ }^{46}$

Although courts are understandably reluctant to depart from a standardized and manageable method of damages, such as market value, the cost of restoring the property owner to his former position generally may be easily ascertained. As applied to the situation in the Evans case, the cost of installing a pump to furnish water to his horses, $\$ 800-\$ 1,000$, would be the amount needed to enable him to continue his prior use without suffering any loss from the county's action. ${ }^{47}$ However, in awarding such costs, there is the possibility of the property owner obtaining a profit as a result of the taking. For instance, if Evans, after receiving the award, was to sell his land at a price determined by its potential use as subdivision land, the amount he receives as compensation for injury to his prior use would result in a "windfall." 48 But this problem can easily be avoided by conditioning payment of the award on the property owner's use of the money to restore or maintain the present use of his property. ${ }^{40}$ Arguably, where the repair cost is considerable, it would be economically wasteful to restore the owner to his former use. A court could therefore conclude that such compensation is not constitutionally required. But where it is impractical to continue the former use, or unreasonable for the property owner

46. See, e.g., Village of Euclid v. Ambler Realty Co., 272 U.S. 365 (1920) (property valuable for industrial potential zoned residential) ; Lionshead Lake, Inc. v. Wayne Township, 10 N.J. 165, 89 A.2d 693 (1952) (minimum size of dwellings); cf. State v. Wicland, 269 Wis. 262,69 N.W.2d 217 (1955) (ordinance requiring approval of architecture of all new buildings).

47. Analogous situations are described in note 41 supra. In a case involving a severance, either the cost of repairs (probably the cost of building an underpass) or the money value of the inconvenience caused would determine the award. In a case involving sct-off benefits that only accrue to the highest use, the award might be based on the earning power of the taken land.

Estimates of such damages occur frequently in partial taking cases arising in rural settings. See, e.g., Hibbets v. Johnson, 342 S.W.2d 642 (Tex. Civ. App.), rev'd on ofher grounds, 350 S.W.2d 330 (Tex. 1961) ; Farr v. State Highway Bd., 122 Vt. 156, 166 A.2d 187 (1960) ; Skinner v. Polk County, 250 Iowa 1264, 98 N.W.2d 749 (1959) ; State Roads Comm'n v. Berry, 208 Md. 461, 118 A.2d 649 (1955); also, see Note, Emincm Damain: Compensation for Partial Taking of Farm Land in Constructing Limited-Access Highways, 42 MrNw. L. Rev. 106 (1957).

48. Evans had already sold some of his land at the time of the appeal, and the court had knowledge of this fact. "A few lots thereon have already been sold." 348 S.W.2d at 502. Thus, the possibility of a windfall may have been an unmentioned factor in the court's decision.

49. In Evans, the court could have decreed a payment of $\$ 800-\$ 1000$ conditioned on Evans having installed a pump. In situations where the detriment to present use is in terms of inconvenience or lost earnings, rather than repairs, compensation might be made by annual payments. If the property owner terminated his less-than-highest use, the payments would cease. Such a method of compensation finds an analogy in Equitable Life Assurance Soc. v. Branham, $250 \mathrm{Ky} .472,63$ S.W.2d 498 (1933), in which an award for personal injuries was ordered paid in monthly installments, with payments to be terminated if the injured party recovered within the three-year payment period, as well as in awards of alimony and in workmen's compensation. 
to insist on such continuance, some award would still seem to be necessary to compensate the owner for the injury resulting from the taking. Although the market value of the property may not be affected by the taking, the owner is deprived of the fruits of his investment in the property from the date of the taking until the property can reasonably be sold at its full market value. Payment, therefore, for lost profits or interest on his investment during this period should be a constitutional minimum of just compensation. ${ }^{\text {.0 }}$

50. In a partial taking where the owner is forced to change his use or sell his property, he receives neither interest from the date of the taking on the compensation awarded, nor the amortization period required in ordinances terminating nonconforming uses, see notes 32-34 supra. Therefore, it would seem necessary to compensate him for his lost profits or interest during the period between the taking and the sale. 